\title{
Variations in gas flaring in Russia observed using multispectral nighttime remote sensing
}

\author{
A. M. Matveev ${ }^{1,2}$, M.N. Zhizhin ${ }^{2,4}$, A.A. Poyda ${ }^{3}$ \\ ${ }^{1}$ Gubkin University, Moscow, 119991, Russia \\ ${ }^{2}$ Space Research Institute RAS, Moscow 117997, Russia \\ ${ }^{3}$ Kurchatov Institute, Moscow, 123098, Russia \\ ${ }^{4}$ Colorado School of Mines, Boulder, CO 80401, USA \\ E-mail: matveevhwre@gmail.com
}

\begin{abstract}
Associated petroleum gas (APG) is an inevitable by-product of oil extraction. In many cases, remote oil production facilities lack infrastructure for associated gas utilization which leads to the disposal of gas through flaring and venting. Gas flaring volumes are usually measured with flow meters; however, these estimates are not usually openly available. As such, spatiotemporal data from satellite remote sensing algorithm VIIRS Nightfire are analyzed within the boundaries of Russia. In this paper, we present major regional and company-level results for 2012-2018 in Russia. Then our estimates are compared with available officially reported data. An example of emergency event impact is examined. Possible economic losses from the gas flaring in Russia are discussed.
\end{abstract}

\section{Introduction}

Associated petroleum gas (APG) is a by-product of oil production which is inevitably released during the oil degassing. There are several ways of the APG utilization, with the refining at gas process sing plants (GPPs) being the most widely used. In many cases, due to the lack of the sufficient APG utilization infrastructure, the gas is disposed through burning (gas flaring) or venting. Substantial volumes of APG may also be flared during emergency or maintenance events. Flaring is not only restricted to the oil upstream facilities but also extends to the gas upstream and most of the downstream facilities.

To assess the impact of the gas flaring on the regional and global scales, some estimates of the total flared volumes are needed. To this day, a primary source of these data are measurements from gas flow meters installed in situ. Although an accurate metering tool with theoretical volumetric error being in the range of 3-7\% [1], the flow meters face a hazardous environment created by APG and are required to operate in a wide range of flow rates. That in practice may result in 20-30\% measurement error [2]. The flaring data are usually restricted to a single facility and are not openly accessible, and in some regions the flow meters may not be installed at all. Thus, the data collected by remote sensing from satellites can be used as an independent instrumental source for global and regional estimates.

In this study we apply VIIRS Nightfire algorithm [3] for the annual gas flaring estimates in 20122018 in Russia. The gas flares detected at night by VIIRS Nightfire were validated using high resolution daytime satellite images. Then the geographical metadata were collected for the confirmed gas flares (section 3.2). As a result, a catalog of gas flares in Russia has been compiled. With this cata$\log$, the annual flared volumes were estimated at the regional and company levels (section 4.1) and 
compared with the reported data on gas flaring and oil extraction (section 4.2). An example of emergency event impact is analysed alongside with the known limitations of the nighttime multispectral remote sensing (section 5.1). Finally, possible economic losses of the observed flaring are estimated (section 5.2).

\section{Gas flaring in Russia: regulations and current status}

According to the Russian Tax Code [4], the associated petroleum gas is extracted via oil wells only*. Flared APG is the main focus of the governmental regulations with higher taxation fees and detailed accounting. Government regulations in force since 2013 aim to achieve $95 \%$ APG utilization while increasing fees for over-limit gas flaring since 2013 [5]. However, there are several major cases in which this coefficient is not applied [5]:

- New oil fields which are in industrial operation less than 3 years.

- Increased volumes of gas flaring at the oil fields due to temporal maintenance at the gas processing plants (GPP).

- Investments into APG infrastructure can be used to cover the over-limit part of the fee.

According to the WWF of Russia [2], complete coverage of flaring facilities with flow meters was reached in mid-2010s. Still it is reported that some companies may use other methods to assess flaring emissions even if the flow meter is installed which may lead to biased interpretation of the data [6]. APG utilization rates at a specific oil field are also a trade secret of the company [7], thus detailed data are rarely publically available. Together with the significant potential error in flow meters, it makes the officially reported data to some degree questionable.

Annual data on gas flaring in Russia at the regional level are available from the Unified Interdepartmental Information and Statistical System maintained by Rosstat (Russian Federal State Statistics Service)**. Regional and company level gas flaring data are also provided by "CDU TEK" (subsidiary of Ministry of Energy) on a commercial basis. Company level data are also published by the major oil companies; however, comparison with the satellite data is complicated because only relative data are published (i.e. APG utilization rate) or it is unclear in which way the joint ventures are accounted.

\section{Methods}

\subsection{VIIRS Nightfire}

This study is based on VIIRS Nightfire algorithm described in detail in [3, 8]. Its estimates are available from the Colorado School of Mines Earth Observation Group webpage: https://eogdata.mines. edu/download_global_flare.html. The method itself is based on multispectral nighttime remote sensing with the emphasis on shortwave infrared (SWIR) observations. According to Wien's displacement law, high temperature heat sources such as volcanos or gas flares have their maximum spectral response in SWIR. As SWIR channel data may be "contaminated" with sun reflectance at daytime, only nighttime observations are used in the algorithm. Multispectral radiances above noise level are then picked to estimate the temperature and area of the detected source using Planck curve modelling. This allows calculating the radiant heat $(\mathrm{RH})$ of the source in megawatts which is then converted into average volume of flared gas using a regression between the two variables.

Preliminary ground-truth validation based on the experimental flare stack with a preset controllable flaring rate shows a strong correlation $R^{2}=0.96$ between the Nightfire RH estimates (in MW) and the gas flow measurements (in lb/hr) [9]. Prior to this, a strong correlation $R^{2}=0.86$ between the RH sum and the expert estimates of the national-level gas flaring by Cedigaz was observed and used for the flared volume estimates in [3]. Relative discrepancy between the two calibrations is within $10 \%$ with

* P. II, a. 337, s. 2, ss. 3: “...Natural fuel gas [...] from all kinds of raw hydrocarbon deposits which is extracted via oil wells (hereinafter referred to as 'associated gas')".

** Manufacturing of main types of products. Unified Interdepartmental Information and Statistical System (UIISS). Rosstat. [In Russian]. Available online: https://fedstat.ru/indicator/40557 and https://fedstat.ru/ indicator/58636. 
the experimental flare results being higher [9]. Because of all this, we assume that the VIIRS Nightfire estimates are well-suited for comparison with the officially reported flared volumes.

\subsection{Validation and obtaining geographical metadata for gas flares in Russia}

Annual clusters of VIIRS Nightfire detections in Russia identified as gas flares were inspected visually using high resolution daytime satellite images available in Google Earth or at https://terraserver.com*. Confirmed gas flares (c. $96 \%$ of automatically identified gas flares) were merged into the gas flaring catalog of Russia containing 2907 separate annual persistent detection clusters.

For these flares, geographical metadata were compiled including coordinates, region, flare type (oil upstream, gas upstream, midstream, oil refinery, gas processing plant, liquid natural gas terminal), name of the oil/gas field or the processing facility, name of the owner company and its subsidiary. All the data were obtained from the open sources, primarily from the oil and gas field map of Russia by "Mineral"** and from the oil and gas field lease information by Rosgeolfond (Russian Geological Fund)***.

\section{Results}

\subsection{Flaring estimates in Russia by major regions and companies}

In 2012-2018, a total number of 2907 VIIRS Nightfire annual persistent heat sources was categorized and validated to be related to gas flares in Russia. Approximately $91-93 \%$ of the estimated flared volumes correspond to upstream oil and gas facilities, with $12-14 \%$ being related to gas fields and processing facilities. For oil and gas condensate fields the VIIRS Nightfire estimates exceed the officially reported volumes by Rosstat from $12 \%$ in 2013 (17.5 vs 15.6 billion $\left.\mathrm{m}^{3}\right)$ up to $80 \%$ in 2016 (19.8 vs $11 \mathrm{bln} \mathrm{m}^{3}$ ). Figure 1 shows that according to Nightfire, gas flaring in Khanty-Mansi and YamalNenets Autonomous Okrugs (KhMAO and YaNAO) is comparable in the recent years.

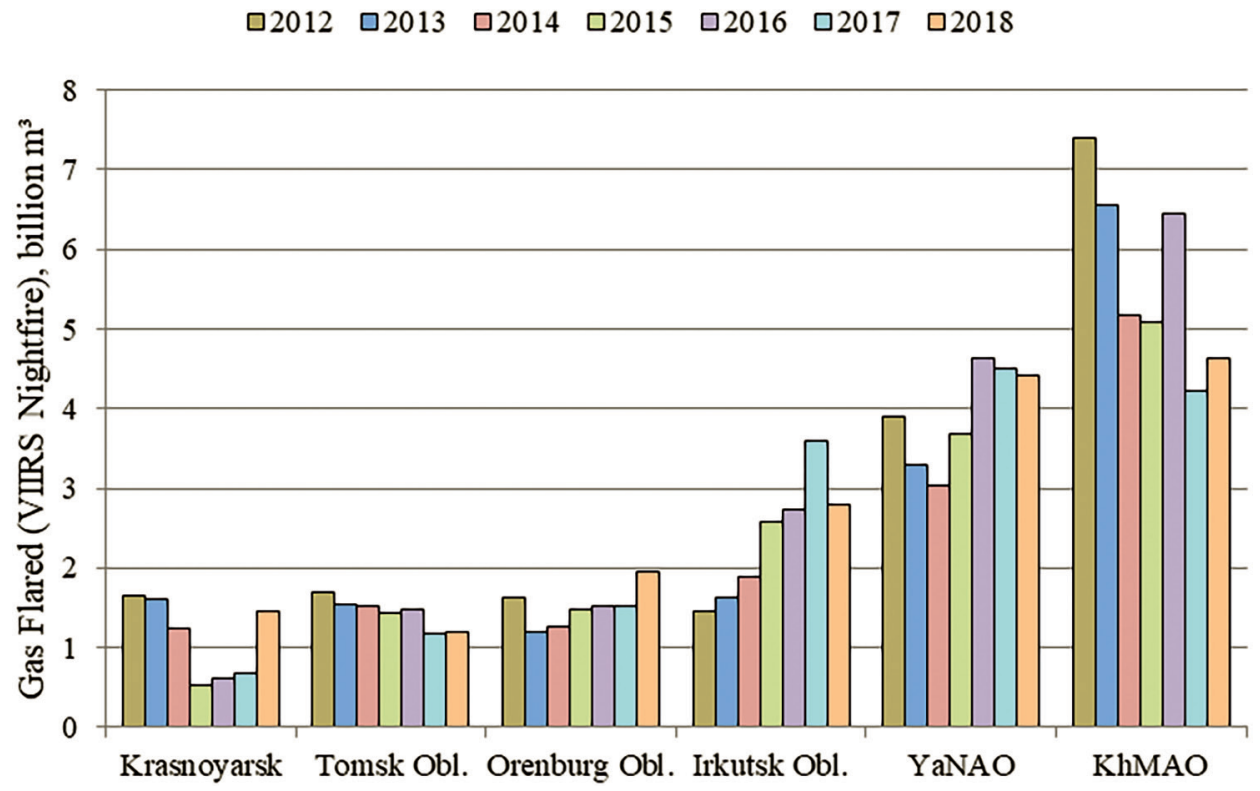

Figure 1. Gas flaring volumes in major $\left(>1 \mathrm{bln} \mathrm{m}^{3}\right.$ per year) flaring regions of Russia.

On the regional level, oil production in KhMAO has dropped from 50 to $42 \%$ during the observation period, while flaring volumes have decreased from 23 to $12 \%$ (reported data) or from 33 to $22 \%$ (Nightfire estimates). YaNAO region is producing only $10 \%$ of oil and gas condensate in Russia;

* We used high resolution space imagery originating from WorldView series of satellites commercially available for browsing in terraserver.com in 2017 and 2018.

** Map of mineral deposits. Research and Analytical Center "Mineral". Available online: https://openmap. mineral.ru/Auth/logon.aspx?1=en\&returnurl=\%2fStandard $\% 2 \mathrm{f} \% 3 \mathrm{fl} \% 3 \mathrm{den}$.

*** Comprehensive analysis of Rosgeolfond database. Rosgeolfond (Russian Federal Geological Fund). [In Russian]. Available online: https://www.rfgf.ru/bal/a/. 
however, relatively high flaring rates are achieved as new fields with insufficient utilization facilities are coming into industrial operation. Substantial flaring is observed in Irkutsk Oblast and Krasnoyarsk Krai (3-4\% of country oil production): in these regions, most of gas flaring corresponds to a small number of fields.

Annual estimates for the major oil companies in Russia are shown in figure 2. Table 1 further specifies average country-level gas flaring volumes and oil production.

$\square 2012 \quad \square 2013 \quad \square 2014 \quad \square 2015 \quad \square 2016 \quad \square 2017 \quad \square 2018$

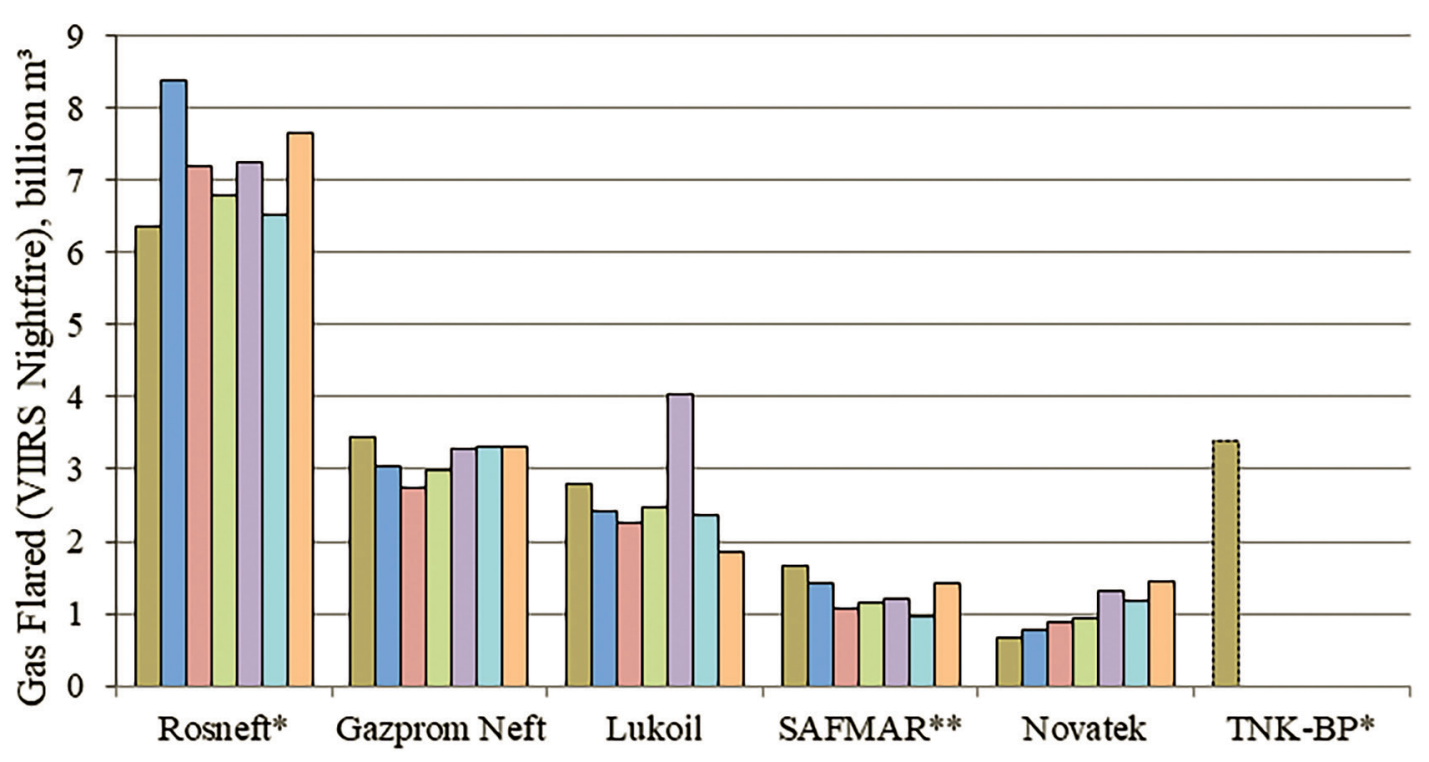

Figure 2. Gas flaring volumes per major flaring oil and gas companies in Russia. * In 2013, TNK-BP was acquired by Rosneft. ** SAFMAR is a group controlling several oil companies (major: Russneft, Neftisa)

Table 1. Major oil company annual gas flaring estimates by Nightfire and oil production volumes adjusted to country level in Russia.

\begin{tabular}{lcc}
\hline Oil Company & Gas Flaring Volumes, \% & Liquid Hydrocarbon Production, \% \\
\hline Rosneft (since 2013) & 35 & $40^{2}$ \\
Gazprom Neft & 15 & $11^{2}$ \\
Lukoil & 13 & $16^{1}$ \\
SAFMAR & 6 & $3^{1}$ \\
Novatek & 4.5 & $2^{2}$ \\
Surgutneftegas & 0.25 & $5^{1}$ \\
Tatneft & 1.2 & $11^{1}$ \\
\hline
\end{tabular}

${ }^{1}$ Including oil production only.

${ }^{2}$ Including oil and gas condensate production.

From table 1 it is evident that three out of four major oil companies in Russia (Rosneft, Gazprom Neft, Lukoil) are also the major sources of flaring. Lower flaring rates are observed for some large oil producers, such as Surgutneftegas and Tatneft.

\subsection{Comparison with regional gas flaring and oil extraction data}

Consistent annual flaring volumes at the regional level are available only for KhMAO. As can be seen in figure 3, the Nightfire estimates deviate from the reported data by a factor of 2 to 3. 2016 volumes stand out from the scatterplot. We assume that it is caused by an emergency event (see section 5.1). With 2016 year data excluded, a strong correlation $R^{2}=0.975$ between the two sources becomes apparent.

Another direction of research can be correlation between estimated gas flaring volumes and oil production rates (also known as Gas-to-Oil Ratio, GOR). According to [10], a significant increase in 
GOR can be observed in the first 5 years of industrial production which is then followed by a steady decline. Such correlation was already observed in the World Bank report on the oil production rates during the Syrian civil war [11].

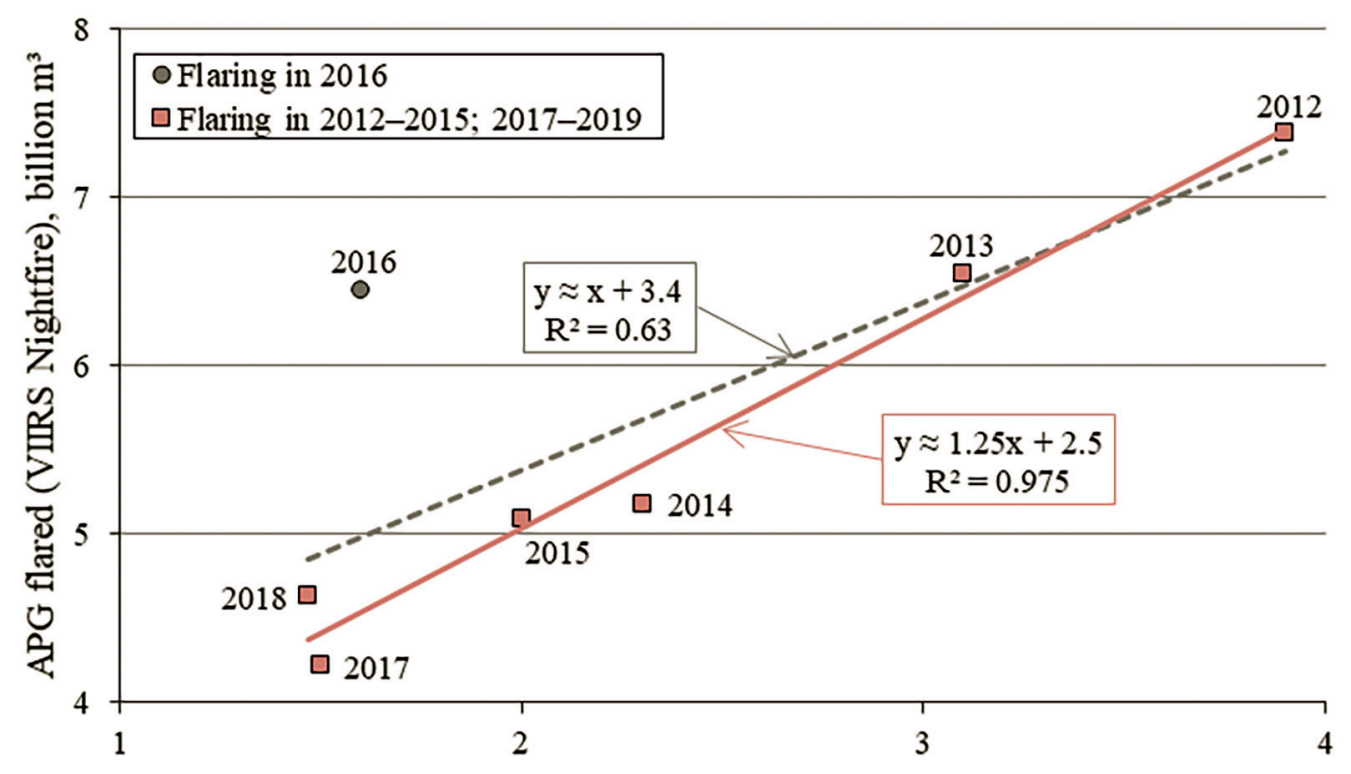

APG flared (Khanty-Mansi AO Department of Subsoil Use), billion $\mathrm{m}^{3}$

Figure 3. Gas flaring volumes in Khanty-Mansi AO according to Department of Subsoil Use $(x)$ and Nightfire estimates $(y)$. Dotted line is the regression including 2016 and solid line excluding it.

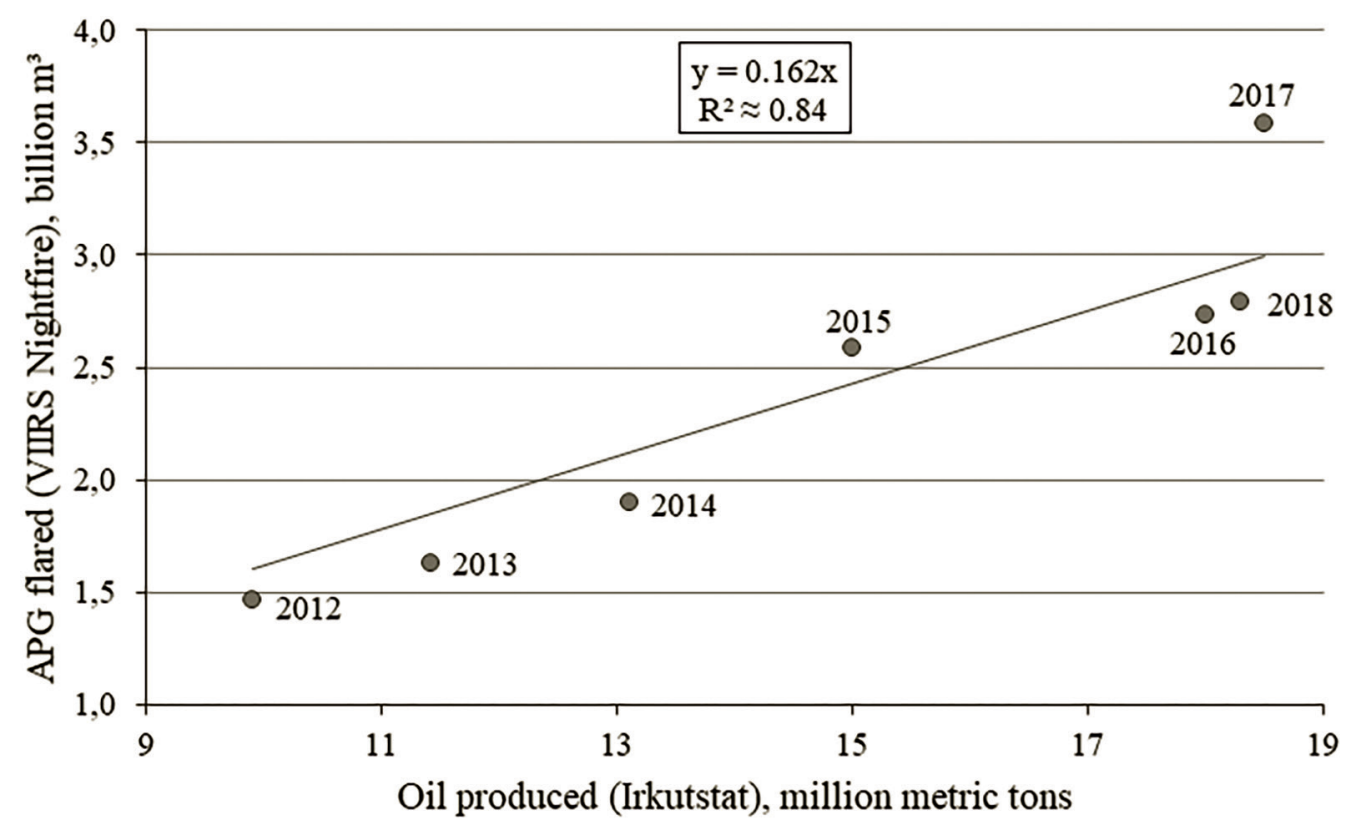

Figure 4. Regression between oil production rates according to Irkutstat $(x)$ and VIIRS Nightfire gas flaring volumes estimates $(y)$ in Irkutsk Oblast.

An example of strong correlation $R^{2}=0.84$ between oil production levels and Nightfire flaring estimates in Irkutsk Oblast is presented in a figure 4. Although the oil production in the region has doubled during the observation period, no major APG refining facilities were connected with the oil fields which led to steady increase in the on-site gas flaring. Lack of the refining facilities is probably the reason of regression through the origin resulting into a strong correlation between the two variables in this case. In the case of KhMAO, a strong correlation $R^{2}=0.85$ is observed as well if we exclude 2016 volumes. However, due to the high APG utilization in KhMAO, the regression will be offset from the origin. 


\section{Discussion}

\subsection{Emergency events}

In section 4.2, the gas flaring estimate in 2016 in KhMAO was found to be an outlier. Examining the data, we found a significant (c. $57 \%$, or $1.2 \mathrm{bln}^{3}$ ) increase in LUKOIL regional gas flaring rates with no increase of such scale observed for any other company in the region. According to LUKOIL annual reports*, no significant change in the production rates occurred this year. However, according to the main Russian news outlet**, an emergency event took place at the major GPP of the company in KhMAO (Lokosovkiy GPP) in the middle 2016 resulting in complete facility shutdown for six month which probably led to the increase of on-site gas flaring in the connected oil fields. According to the company annual report, refining capacity of the GPP is c. $0.75 \mathrm{bln} \mathrm{m}^{3}$ in six months; however, an estimated spike in flaring is $1.2 \mathrm{bln} \mathrm{m}^{3}$.

As no flaring spike is observed in the reported data, it is plausible that the emergency flared volumes were not considered as over-limit according to the state regulations as the flaring occurred during maintenance or repair procedures.

\subsection{Economic losses from gas flaring in Russia}

Rough estimates of economic losses from gas flaring in Russia were conducted based on the available data by Rosstat, Inter RAO (major Russian power generation company), Sibur (major Russian petrochemical producer), and Khanty-Mansi administration. The losses are calculated as a revenue in average annual prices. APG could be used as:

- A raw commercial product. As such, it is equal to 0.6-1.2 USD bln***.

- A fuel for power generation. As such, it accounts for 0.8-1.7 USD bln. According to these estimates, flared gas volume could provide electric power for the country of Russia for one month in summer (c. $70000 \mathrm{GW} \cdot \mathrm{h})$.

- A product for further refining. In our estimates we have used technology systems of APG utilization mentioned in [12]. As there are several stages of processing, the estimates range from 1.6 to 5.9 USD bln.

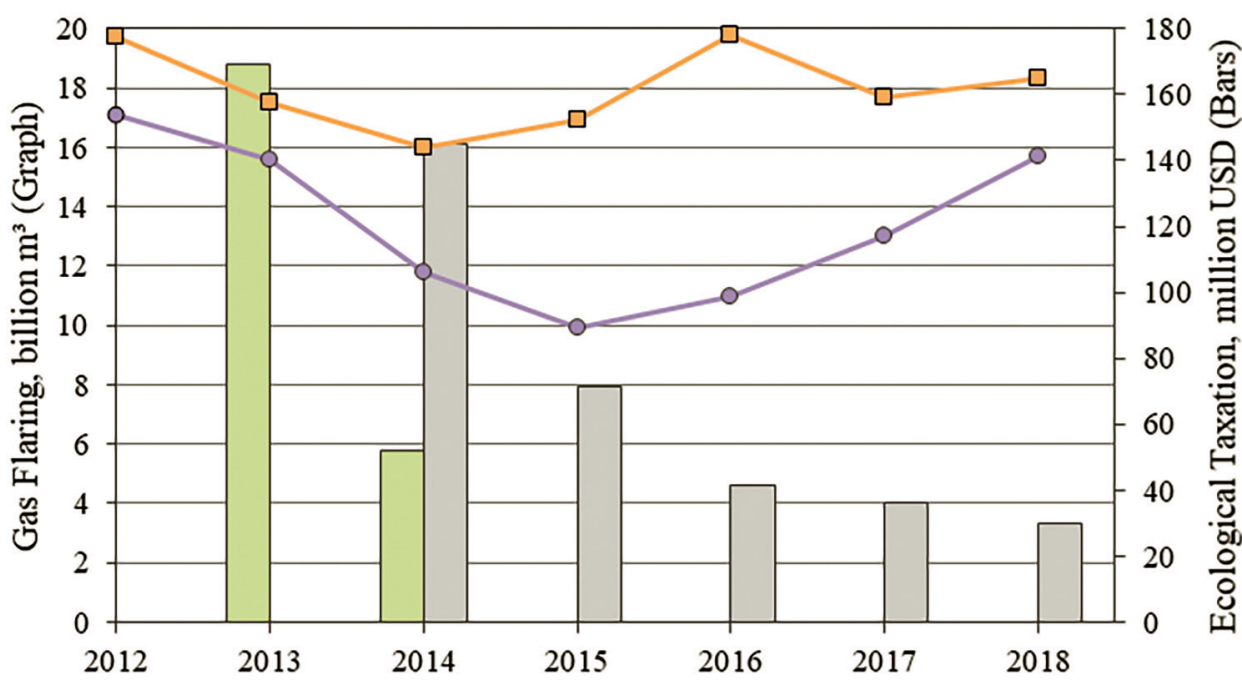

Figure 5. Gas flaring rates and ecological fees in Russia. Graphs (left axis) indicate flaring rates, bars (right axis) represent budget receipts per [13] (left bar) and [14] (right bar).

* LUKOIL Annual Reports. Available at: https://www.Lukoil.com/InvestorAndShareholderCenter/ ReportsAndPresentations/AnnualReports.

** Four Men Injured Following a Fire on a LUKOIL's GPP in KhMAO. TASS. 29.06.2016 [In Russian]. Available at: https://tass.ru/proisshestviya/3415135.

*** During 2014, RUB to USD exchange rate rapidly increased by a factor of $\sim 2$ (ruble depriciated). This leads to a wide range of revenue calculations in USD during the observation period. 
Alternatively, ecological taxation of gas flaring can be presented for comparison. Paired with the annual gas flaring volumes, annual ecological taxation is presented in figure 5.

According to the report by the Minister of Natural Resources and Environment of Russia, the final taxes in 2013-2014 accounted for 170 and 50 USD mln respectively, while investments in utilizing infrastructure have covered as high as 900 USD mln annual over-limit fees [13]. Rosprirodnadzor (Russian Federal Supervisory Natural Resources Management Service) data indicate that gas flaring emission fees dropped from 70 to 30 USD mln in 2014-2018 [14]. From figure 5, it can be seen that budget income has dropped considerably in 2014-2015 with the reported flaring volumes dropping as well. At the same time Nightfire estimates indicate a slight growth in flaring activity. This increase in the flaring activity is supported by the fact mentioned by WWF Russia: in 2015, reported APG production rates dropped by $10 \%$ while oil production grew by $1.3 \%$ which is impossible in practice [2]. The origin of continuing decline in ecological taxation fees amid the growth in flared volumes in 2016 onwards remains unclear. Our estimates for 2016 ecological fee based upon Nightfire flaring volumes approximated at 8.7 RUB bln (130 USD mln). However, accuracy of this assessment is limited as field-specific data required for precise calculations are missing.

\section{Summary}

A strong correlation is observed between VIIRS Nightfire estimates, preliminary experimental results based on a test flaring facility with a preset flow rate and high accuracy gas flow meter [9] and independent country-level expert estimates by Cedigaz [3].

Considering only oil upstream facilities, the Nightfire estimates in 2012-2018 exceed flaring volumes reported by Rosstat from $12 \%$ in 2013 (17.5 vs 15.6 billion $\mathrm{m}^{3}$ ) up to $80 \%$ in 2016 (19.8 vs 11 billion $\mathrm{m}^{3}$ ). Khanty-Mansi and Yamalo-Nenets Autonomous Okrugs (KhMAO and YaNAO, respectively) are the major flaring regions in Russia (4-5 billion $\mathrm{m}^{3}$ in 2016-2018). In KhMAO, gas flaring has dropped significantly (by 2.7 billion $\mathrm{m}^{3}$, or $35 \%$ ) since 2012. Flaring rates of the major oil companies usually correspond to their oil production volumes; however, in cases of Tatneft and Surgutneftegas their flaring rates are significantly lower than production levels.

In case of KhMAO, Nightfire estimates show a strong correlation $R^{2}=0.95$ with reported flaring volumes, although 2016 estimates appear to be significantly higher, probably due to an emergency event. Also, several cases of strong correlation $R^{2}>0.8$ between gas flaring estimates and officially reported oil production volumes are presented for several regions.

A strong impact from an emergency shutdown of gas processing plant was detected using the remote sensing estimates. However, the estimated "over-flared" volumes exceed the expected shutdown refinery capacity by factor 1.5 .

During the observation period, the annual economic losses in terms of revenue from possible produced commodities from flared APG were estimated to be from 0.6-1.2 USD bln (raw APG commercial value) up to 1.6-5.9 USD mln (petrochemical products). For comparison, the officially reported environmental fees caused by flaring have dropped from 170 to 30 USD mln in 2013-2018 amid the growth in the total flared volumes.

\section{References}

[1] Guidelines on Flare and Vent Measurement: Technical Report / Clearstone Engineering Ltd., 200836 p., available at: http://documents.worldbank.org/curated/en/689451468158369316/pdf/713800WP0Box370a re0Vent0Measurement.pdf.

[2] Knizhnikov A., Ilyin A., Associated Gas Utilization in Russia: Issues and Prospects: Annual Report, 2017, Moscow: WWF Russia, 2017, 34 p., available at: https://wwf.ru/resources/publications/booklets/ problemy-i-perspektivy-ispolzovaniya-poputnogo-neftyanogo-gaza-v-rossii-2017/.

[3] Elvidge C.D., Zhizhin M., Baugh K. E., Hsu F.C., Ghosh T., Methods for Global Survey of Natural Gas Flaring from Visible Infrared Imaging Radiometer Suite Data, Energies, 2016, Vol. 9(1), 15 p.

[4] Federal Law No. 117-FZ of August 5, 2000 "Tax Code of the Russian Federation. Part II" (ed. 31.07.2020), 729 p., Available at: https://www.nalog.ru/html/sites/www.eng.nalog.ru/Tax\%20Code\%20Part\%20Two.pdf.

[5] Regulation of the Government of the Russian Federation of 08 November 2012 No. 1148 (ed. 13.12.2019) “On particularities of calculation of fee for emission of pollutants in course of burning at flare facilities and (or) deflation of oil-associated gas”, available at: http://lecap.ru/upload/iblock/3a1/3a107fcc 1544b95dd2187409 2ce33574.pdf. 
[6] Korppoo A., Russian associated petroleum gas flaring limits: Interplay of formal and informal institutions, Energy Policy, 2018, Vol. 116(C), pp. 232-241.

[7] Nizhegorodov A., Associated Petroleum Gas: Refine, not Flare, Neftegaz.ru, 2017, Vol. 10, available at: https://neftegaz.ru/science/view/1404-PNG-szhigat-nevygodno-pererabatyvat.

[8] Elvidge C. D., Zhizhin M., Hsu F. C., Baugh K. E., VIIRS Nightfire: Satellite Pyrometry at Night, Remote Sensing, 2013, Vol. 5, pp. 4423-4449.

[9] Zhizhin M.M., Elvidge C.D., Kodesh Z., Ground-truth Validation of VIIRS Nightfire for Gas Flaring Estimates, $47^{\text {th }}$ Global Monitoring Annual Conf., 2019, p. 16.

[10] Filippov A., Gas-to-Oil Ratio and Associated Petroleum Gas Metering, Neftegaz.ru, 2013, Vol. 7-8, available at: https://neftegaz.ru/science/general-questions/331893-gazovyy-faktor-i-uchet-poputnogoneftyanogo-gaza/.

[11] Do Q.T., Shapiro J. N., Elvidge Ch. D., Abdel Jelil M., Ahn D.P., Baugh K., Hansen-Lewis J. N., Zhizhin M. How Much Oil is the Islamic State Group Producing? Evidence from Remote Sensing, Policy Research working paper, 2017, WPS8231, Washington, D.C.: World Bank Group, 2017, 54 p., available at: https://documents.worldbank.org/en/publication/documents-reports/documentdetail/239611509455488520/how-much-oil-is-the-islamic-state-group-producing-evidence-from-remotesensing.

[12] Kiryushin P., Knizhnikov A., Kochi K., Puzanova T., Uvarov S., Associated Gas Utilization in Russia: "Refine, not Flare”, Moscow: WWF Russia, 2013, 88 p., available at: https://wwf.ru/resources/ publications/booklets/poputnyy-neftyanoy-gaz-v-rossii-szhigat-nelzya-pererabatyvat-/.

[13] Donskoy S., Increasing Associated Petroleum Gas Utilization in Russia, $4^{\text {th }}$ Global Forum of the World Bank "Solutions to reduce gas flaring”, available at: https://vygon.consulting/upload/iblock/a4d/donskoy_globalnyy_forum_png_20150908.pdf.

[14] Information on the Ecological Taxation Fees and Improving Administration Efficiency-2019, Moscw: Rosprirodnadzor, 2019, available at: http://gkeco-nn.ru/images/docs/DRPN_Presentation.pdf. 